\title{
LUMP-SUM DISTRIBUTIONS FROM \\ RETIREMENT SAVING PLANS: \\ RECEIPT AND UTILIZATION
}

\begin{abstract}
One of the central issues in evaluating the ongoing shift from defined benefit (DB) to defined contribution (DC) pension plans is the degree to which assets in DC plans will be withdrawn before plan participants reach retirement age. The annual flow of withdrawals from such plans, which are known as lump sum distributions and which are frequently but not always associated with employment changes, has exceeded $\$ 100$ billion in recent years. This flow is substantially greater than the flow of new contributions to IRAs and other targeted retirement saving programs. This paper draws on data from the 1993 Current Population Survey and the Health and Retirement Survey to summarize the incidence and disposition of lump sum distributions. We find that while less than half of all lump sum distributions are rolled over into IRAs or other retirement saving plans, large distributions are substantially more likely to be saved than smaller ones are. Consequently, more than half of the dollars paid out as lump sum distributions are reinvested. We also explore the correlation between various individual characteristics and the probability of rolling over a lump sum distribution. This is a first step toward developing a model that can be used to evaluate the long-term effects of lump sum distributions, or policies that might affect them, on the financial status of elderly households.
\end{abstract}

James M. Poterba

Department of Economics

E52-350

Massachusetts Institute of Technology

Cambridge, MA 02139-4307

and NBER

David A. Wise

Kennedy School of Government

Harvard University

79 JFK Street

Cambridge, MA 02138

and NBER
Steven F. Venti

Department of Economics

6106 Rockefeller Center

Dartmouth College

Hanover, NH 03755

and NBER 
The degree to which alternative pension systems preserve retirement benefits when individuals change jobs has long been a consideration in evaluating various retirement saving arrangements. Related preservation issues have also been raised with respect to targeted retirement saving accounts, such as Individual Retirement Accounts and 401(k) plans, which permit contributors to withdraw funds, subject to a tax penalty, before they reach retirement age. As the incidence of targeted retirement saving plans increases, the number of taxpayers with the potential to trigger such withdrawals will also increase. Although a number of previous studies, including our own (1994a, 1995), have examined the determinants of participation and contribution behavior in retirement saving plans, withdrawal behavior has received much less attention.

The incidence and disposition of withdrawals from pension plans or other saving plans, known as lump sum distributions, is a key determinant of the financial status of elderly households. Consider a 35-year-old who has accumulated $\$ 10000$ in a defined contribution pension plan, and who changes jobs. If these funds remain in a defined contribution pension account and earn a 5 percent annual real return, the balance in this plan will be $\$ 44817$ when the beneficiary reaches age 65 . If these funds are withdrawn and consumed when the pension plan participant changes jobs, however, they will not contribute to 
his financial well-being in retirement. Because a high fraction of lump sum distributions occur when individuals change jobs early in their employment career, withdrawing such assets foregoes the opportunity for many years of compound accumulation at pre-tax rates of return.

This paper considers the incidence and disposition of lump sum distributions from pension plans and targeted retirement saving accounts, and it presents exploratory empirical evidence on recipient characteristics that are correlated with the decision to roll-over such distributions and preserve their associated retirement benefits. Although we are particularly interested in withdrawals from IRAs and $401(k)$ plans, we are not aware of any data source that provides detailed information on these withdrawals as distinct from distributions from DB and DC pension plans. At least historically, payouts from pension plans are likely to account for the substantial majority of distributions. We therefore explore the general pattern of receipt and utilization of all distributions.

The paper is divided into five sections. Section one presents descriptive information on the nature and tax treatment of lump-sum distributions. The next section summarizes previous work on the incidence and utilization of these distributions, noting an apparent disparity between estimates of the number of these distributions based on IRS information return filings and estimates based 
on self-reports in sample surveys. Section three describes the two data sets that we use to analyze the incidence and utilization of lump sum distributions: the April 1993 Employee Benefits Supplement to the Current Population Survey, and the first wave of the Health and Retirement Survey. This is followed by a summary of the patterns of lump sum distribution receipt in these two surveys.

Section four presents evidence on the utilization of lump sum distributions and the factors that are related to decisions to save these distributions. We find that the probability that a distribution is saved or rolled-over into a targeted retirement saving account such as an IRA rises with the size of the distribution, the age of the recipient, and the income and education of the recipient. These patterns suggest that individuals who are likely to have accumulated more assets by retirement are less likely to consume premature lump sum distributions. The paper closes with a brief section suggesting a number of directions for future work.

\section{Background Information: What Are Lump Sum Distributions?}

Lump sum distributions can arise in conjunction with defined contribution (DC) or defined benefit (DB) pension plans, $401(k)$ or $403(b)$ retirement saving plans, or Individual Retirement Accounts. Such distributions are defined as premature if they are received before the retirement plan participant reaches 
age $59 \frac{1}{2}$ or dies. Distributions may be voluntary, for example when an individual elects to withdraw funds from a 401 (k) plan without any change in employment status, or involuntary. Involuntary distributions are usually triggered by changes in employment status, and they result when an employer elects to "cash out" a former employee's assets in a pension plan.

Defined contribution plans, which maintain separate accounts for each individual participant, typically make lump-sum distributions when participants retire or terminate their employment before retirement. The rapid growth of defined contribution pension plans since the passage of ERISA has increased the actual and potential importance of lump sum distributions. Lump sum distributions can also arise when vested employees terminate employment at firms that offer defined benefit pension plans. ERISA permitted employers who sponsor DB plans to "cash out" terminated employees, without the employee's consent, if their accrued benefits were less than $\$ 1750$. This limit was raised to $\$ 3500$ by the Retirement Income Act of 1984 .

Lump sum distributions are included in taxable income in the year when they are received, although the tax burden on such distributions may be reduced in some cases. Prior to 1986, taxpayers receiving these distributions could elect a 10-year forward averaging option on their distributions, in essence distributing their distribution across ten tax years. This provision was repealed 
in 1986, when the Tax Reform Act (TRA86) replaced it with a five-year forward averaging option for taxpayers over the age of $59 \frac{1}{2}$. Each taxpayer may elect such forward averaging once in his lifetime.

A number of tax code provisions that have been enacted in the last decade encourage individuals who receive lump-sum distributions before the age of $59 \frac{1}{2}$ to preserve these distributions for prospective retirement income. TRA86 imposes a 10 percent excise tax on pre-retirement distributions to taxpayers younger than age $59 \frac{1 / 2}{{ }^{1}}$ In addition, 1992 legislation imposed a 20 percent withholding tax on distributions received before age $59 \frac{1 / 2}{2}$ if these distributions are not rolled over into a tax qualified investment vehicle. This withholding tax does not affect the total tax liability of lump sum distribution recipients, but it does affect the timing of taxes. It implies that those who do not elect a fiduciary-to-fiduciary transfer do not receive the full amount of their distribution, but rather receive 80 percent of the amount of the distribution. There is some evidence that the share of lump sum distributions that are rolled over into qualified retirement saving plans has increased over time. This is probably due in part to the enactment of these tax incentives.

\footnotetext{
${ }^{1}$ The penalty tax is waived if the recipient converts the distribution to an annuitylike stream of payments, if the recipient is disabled, or if the distribution is triggered by the death of the plan participant.
} 
Lump sum distributions are an important factor in the evolution of total asset balances in targeted retirement saving accounts. Because many such distributions are rolled into IRAs, we consider these accounts. In tax year 1990, taxable income from IRA distributions equaled $\$ 17.5$ billion, greater than the $\$ 15.6$ billion of "ordinary" contributions made by 9.3 million taxpayers contributing to these accounts. ${ }^{2}$ Yakoboski's (1994) tabulation of IRS Form 1099-R and 5498 filings shows that in 1990, 8.2 million recipients received $\$ 107.2$ billion in lump-sum payouts. Of these recipients, 3.1 million rolled over their distributions into IRAs, with a total rollover of $\$ 71.4$ billion. $^{3}$ This is a lower bound for the extent of roll-overs, since it does not include roll-overs into 401(k) plans or other qualified defined contribution plans, because such rollovers do not trigger Form 5498 filings.

${ }^{2}$ Tabulations from Form 1040 show 5.2 million contributions, contributing $\$ 9.9$ billion, to IRAs in 1990 . This is substantially lower than the $\$ 15.6$ billion estimate of contributions for two reasons. First, non-deductible IRA contributions are not indicated on Form 1040. Second, contributions to SEP-IRAs are not aggregated with IRA contributions on Form 1040, but they are combined on Form 5498, which is the basis for the $\$ 15.6$ billion estimate. SEP-IRAs are a pension plan arrangement that allows an employer to make contributions to his or her own IRA (if self-employed) as well as to each employee's IRA. The individual sets up an IRA, and then the employer contributes to this account up to a maximum of $15 \%$ of compensation or $\$ 30,000$.

${ }^{3}$ The flow of rollovers increased over the time period for which the IRS data are available, from $\$ 39.3$ billion in 1987 , to $\$ 45.9$ billion (1988), $\$ 63.0$ billion (1989), and $\$ 71.4$ billion (1990). 
To place the various flows into and out of IRAs and related accounts in perspective, it is helpful to consider the flows during calendar year 1990. At the beginning of the year, the balance in IRAs and Keogh plan accounts was $\$ 501.7$ billion. Ordinary IRA contributions totaled $\$ 15.6$ billion during 1990 , and withdrawals amounted to $\$ 17.5$ billion. Rollovers were $\$ 71.4$ billion, or nearly the change during the year in the value of assets held in these accounts.

A direct way to estimate the flow of distributions that are not rolled over relies on taxes collected on premature distributions from IRAs and other qualified retirement plans. Line 52 of Form 1040 indicates the amount of this tax, which was $\$ 1.196$ billion in 1990 . Since the tax rate on withdrawals is $10 \%$, this revenue flow grosses up to approximately $\$ 12$ billion in distributions. This value is an upper estimate for the flow of premature distributions, since the tax shown on line 52 can be triggered by any of four events: a premature withdrawal from an IRA or qualified defined contribution pension plan; an excess contribution to an IRA; excess accumulation in a qualified retirement plan; or an excess distribution (in excess of $\$ 150,000$ in one year) from a qualified retirement plan.

Table 1 presents more detailed information on the nature of lump-sum distributions as reported in Yakoboski's (1994) tabulation of IRS Form 1099-R data. The distributions are divided into two broad groups, which can be 
distinguished on tax forms: those from IRA/SEP-IRA accounts, and those from other accounts. Payouts from defined benefit and defined contribution pension plans, and $401(\mathrm{k})$ plans, would appear in the "Other" category. The table shows that in 1990 , more than half of all distributions were premature, i.e. to recipients who had not yet reached age 591/2. Premature distributions accounted for only $32 \%$ of all distributions, however. Distributions triggered by the death of a pension plan participant account for $6 \%$ of the value of all distributions. Normal distributions, such as payouts to individuals over age $59 \frac{1}{2}$ who are retiring from a firm with a defined contribution pension plan, account for $21 \%$ of all distributions but $33 \%$ of all distributed dollars.

We have not presented detailed tabulations on the characteristics of lump sum distribution recipients; these are available in EBRI (1994) and elsewhere. Several points are nevertheless worth noting. In the 1993 CPS survey, 11 percent of the respondents who received a lump sum distribution reported that this distribution was less than $\$ 500$, another 20 percent that it was between $\$ 500$ and $\$ 1000$, and a further 20 percent received distributions between $\$ 1000$ and $\$ 2500$. More than sixty percent of all distributions were for less than $\$ 5000$.

Previous tabulations also show that most lump sum distribution recipients are relatively young. EBRI (1994) reports that 39 percent of recipients reported 
that their most recent distribution was received before they turned 30 , with another 36 percent of respondents receiving distributions between the ages of 31 and 40 . Thus most distributions are small and are received relatively early in life, in part reflecting the greater degree of job mobility during this part of the lifecycle.

\section{Previous Research on Lump Sum Distributions}

A number of previous studies have analyzed the potential for lump-sum distributions as well as the utilization of these distributions by those who receive them. Most of these studies have relied upon data from the Current Population Survey (CPS) supplements on Employee Benefits, which were conducted in $1979,1983,1988$, and 1993 . We are not aware of any previous work that has analyzed the HRS data on lump sum distributions.

One of the first studies of lump sum distributions is Atkins (1986), who presents information from the 1983 CPS EBS. He related the probability of saving a lump sum distribution to individual characteristics. He concluded that most distributions were spent, not saved, and that the groups with substantial saving probabilities were older, better-educated, and those who received larger

distributions. Our findings based on the 1993 CPS supplement confirm many of these patterns. 
The growth in lump sum distributions during the 1980 s drew increased attention to these payouts. Andrews (1991), Chang (1993), EBRI (1989), Fernandez (1992), and Piacentini (1990) all analyze the 1988 CPS EBS data on the receipt and utilization of lump sum distributions. Fernandez (1992) and Piacentini (1990) present largely descriptive information. Fernandez (1992) summarizes the data available in the 1988 survey, and presents some comparisons between the 1983 and 1988 EBS. She finds that 8.5 million workers reported having received at least one lump-sum distribution from a previous employer's pension plan. She also finds a substantial increase in the fraction of lump sum distributions that are rolled over into qualified retirement saving vehicles such as IRAs between the 1983 and 1988 CPS surveys. ${ }^{4}$

Andrews (1991) and Chang (1993) also analyze the 1988 EBS, but their studies develop formal econometric models for recipient behavior. Andrews (1991) analyzes the determinants of rollover behavior; her work in some ways resembles our analysis of the 1993 EBS data. She models both the probability that a given respondent will report having received a lump sum distribution, as well as the factors that affect the allocation of that distribution. Her definitions

${ }^{4}$ EBRI's (1989) analysis of the 1988 data is broader than Fernandez' (1992) focus on lump sum payouts. It includes summary tabulations for other variables that are included in the supplemental survey. Piacentini (1990) includes a broader discussion of current public policies that affect the preservation of retirement benefits. 
of "saving" are substantially broader than those in our study, since she considers distributions that are used to buy a house or pay a mortgage, used to start a business, or used to pay other debts as "saving." Her results nevertheless suggest a number of interesting patterns, including a higher probability of saving distributions by households that have made contributions to an IRA, and by those who receive interest or dividend income. She does not find substantial effects of education on the probability of saving a distribution, a result that is contrary to our findings below and to Atkins (1986) findings with the 1983 EBS.

Chang's (1993) study concentrates on the effect of the 10 percent excise tax on premature distributions, enacted in 1986, on the utilization of lump sum distributions. She compares the use of distributions by those who received distributions before and after 1986, and concludes that the excise tax reduced the probability of consuming a distribution by approximately six percentage points.

The most recent CPS supplementary survey on employee benefits, the April 1993 survey, has already been the basis for several studies of lump sum distributions. EBRI (1994) presents detailed summary information on many variables from the 1993 EBS including those related to lump sum distributions. This study is an extremely valuable source of background information, but it is 
largely confined to studying rollover behavior along single dimensions of individual characteristics, such as income or age. Gelbach (1995), another study that is closely related to our analysis of saving decisions, uses the 1993 EBS to estimate a multinomial logit model for whether households roll over their distributions into an IRA, save them in other ways, or spend them. His results suggest that older recipients, and those who receive larger distributions, are substantially more likely to save these distributions than are younger recipients of small distributions.

As this brief summary demonstrates, we are hardly the first group of researchers to explore household behavior with respect to lump sum distributions. Our analysis differs from that in most previous studies in our use of a new data base, the Health and Retirement Survey, and in our consideration of several potential definitions of saving, including a strict definition (rolled over into an IRA) and a more general definition encompassing other non-consumption uses of a lump sum distribution.

\section{Data Sources and Summary Statistics}

Our analysis relies on two sources of information on lump sum distributions and their utilization: the May 1993 Employee Benefits Supplement to the Current Population Survey, and the Health and Retirement Survey. We 
begin with brief descriptions of these surveys, and then summarize the information on lump sum distributions contained in each.

\subsection{CPS-Based Evidence on Lump Sum Distributions}

The CPS EBS questionnaire was administered to a representative subsample of over 27,000 CPS survey participants in April 1993. It contains detailed information on pension plan coverage, access to employer-provided health insurance, as well as on a respondent's experience with lump sum distributions. ${ }^{5}$ The relevant questions on these distributions began with the question "Have you ever received a lump-sum payment from a pension plan or retirement plan on a previous job?" Those who responded affirmatively to this question were then asked about the year in which they received the lump sum payment, the approximate amount of this payment, and were asked to indicate how they spent or invested the distribution. The latter question offered a variety of options, such as "rolled over into an IRA" and "put into a savings account," and respondents were permitted to select more than one response without indicating the fraction of the distribution that was allocated to each

${ }^{5}$ The Employee Benefit Research Institute (1994) presents a detailed set of tabulations for many of the questions included in the May 1993 EBS. 
use. The CPS top-codes responses to the value of the lump sum distribution at $\$ 100000$.

Two features of the CPS data deserve note. First, if a respondent had received more than one lump-sum distribution, he was directed to confine his answers to the most recent distribution. This implies that the historical aggregate flow of lump sum distributions recorded in the CPS will understate actual distributions, with greater overstatement at earlier dates. ${ }^{6}$ This feature of the CPS data should be contrasted with the Health and Retirement Survey, which collects information on multiple distributions. Second, the question is restricted to distributions received from a former emplover. This means that, for example, an individual who had received a lump sum distribution from his current employer's $401(\mathrm{k})$ plan, perhaps by withdrawing his employee contributions to this plan, would not be identified as a recipient of a lump sum distribution.

In the 1993 CPS Employee Benefit Supplement, 2736 respondents indicated that they had received a lump sum distribution. Of this group, $31 \mathrm{did}$ not respond to the question on how the distribution was used. This left a

${ }^{6}$ Approximately $31 \%$ of the lump sum distributions described by EBS participants were received after $1985,25 \%$ after 1990 . One sixth were received before 1980 . 
sample of 2705 respondents for our study. Using the sample weights in the CPS, this group corresponds to 11.7 million individuals in the U.S. population.

Table 2 presents summary information on the probability of ever having received a lump sum distribution by age groups in the $1993 \mathrm{CPS}^{7}$ The table, which is stratified by age of the respondent in 1993, mixes the effect of aging within a given cohort and differential experience of different cohorts. It shows that the probability of ever having received a distribution rises as one considers older workers up to roughly age 40 , but the probability is relatively stable thereafter. Table 2 presents separate tabulations for men and women, and shows that the rates of distribution receipt do not differ substantially between young men and women, although older women are less likely to have received such distributions than their male counterparts. This presumably reflects their lower probability of having been covered by employer provided pensions.

In addition to information on who receives lump sum distributions, the Employee Benefits Supplement also contains data on the disposition of such distributions. Respondents are allowed to indicate more than one use of their lump sums, although only one sixth of the respondents actually indicated more

${ }^{7}$ In both Table 2 and Table 4, we identify the universe of individuals who could have received lump sum distributions by conditioning on a non-missing response to the CPS question about the size of the firm that the individual currently or previously worked for. This restriction eliminates an additional 108 respondents with lump sum distributions from our analysis. 
than one use. Table 3 presents summary results on the uses to which these distributions were put. The table focuses on two age groups, all ages and the subgroup that corresponds to the Health and Retirement Survey participants. It also presents two tabulations for each age group, one reporting the fraction of distribution recipients in each category, the other the fraction of distribution dollars by category.

The table shows that a relatively small fraction of lump sum distribution recipients roll their distributions into an IRA or the retirement plan administered by their new employer. If we consider "saving" a lump sum to include IRA or employer plan rollovers, investment in an IRA, an annuity, or a savings account, then the overall probability that a lump sum distribution will be saved is $\mathbf{3 3 . 2}$ percent. $^{8}$ The table illustrates, however, that this probability is much higher if distributions are weighted by their value. In this case, the probability of preserving a lump sum distribution is $58.6 \%$. Table 3 also shows that recipients use lump sum distributions for a wide range of purposes, with repayment of debts or bills as the largest single item after saving. Comparing the various columns in Table 3 suggests relatively small differences in the

\footnotetext{
${ }^{8}$ Saving could in fact be defined much more broadly, to include reductions in debt, purchases of consumer durables, and similar transactions that do not reduce household net worth are current consumption would. The probability of such expanded saving measures can also be computed from the data in Table 2 .
} 
disposition of lump sum distributions between those currently approaching retirement and younger workers. In part, this reflects the fact that older workers who are reporting on lump sum distributions may have received these distributions much earlier in their working careers.

\subsection{HRS-Based Evidence on Lump Sum Distributions}

The Health and Retirement Survey (HRS) is a new panel survey designed to collect information on households as they approach retirement. Its sampling frame is the population between the ages of 51 and 61 in 1992, with some oversampling of Florida residents and those who live in heavily Black or Hispanic areas. The full HRS sample includes just over 12,000 respondents, so it is substantially smaller than the CPS. For the relevant age range, however, the CPS and HRS are likely to yield results of similar precision. Our analysis relies on the first wave of the HRS, which was collected in 1992.

The HRS includes a detailed battery of questions on pension coverage at current and previous employers. If the respondent is currently employed and indicates that he worked at a previous employer for more than five years, he is asked if he was included in a pension or retirement plan, or tax-deferred saving plan, at that job. If he is retired, he is asked about the pension plan at his last employer. In both cases, the respondent is then asked whether the retirement 
plan was a defined benefit or defined contribution plan, and what happened when he left that employer. One of the potential responses at this stage is "cash settlement," and another is "rolled over into an IRA." For those who received a cash settlement, they are subsequently asked the amount of the settlement, and if they spent this settlement, saved and invested it, paid off debts, or rolled the settlement into an IRA. One difficulty with the HRS data is that respondents who rolled payouts from previous employer plans into their new employer plans, or who used the proceeds to purchase insurance annuities, were not asked about the amount of these distributions. Thus HRS-based tabulations that use information on distribution amounts are limited to a subsample of all distribution recipients.

Table 4 presents summary information on lump sum distribution recipients in the HRS. Because of the limited age variation within HRS, the data are not stratified by age, as in Table 2, but by the current labor income of the respondent. For comparison, Table 4 presents similar stratification from the entire sample of CPS respondents, and from the subset of CPS respondents whose ages in 1993 conform to the HRS respondents. The HRS data show a rising probability of ever having received a lump sum distribution as the respondent's current income rises. 
The same pattern is observed in the CPS data, but with two notable differences. First, the rate of lump sum distribution receipt in the HRS sample is nearly four percentage points higher than that in the all-age CPS sample. Nearly half of this disparity is apparently due to the age criterion used to select the HRS sample, but the last column in Table 4 shows that even the HRS-aged subsample of the CPS displays a lower incidence of lump sum distribution receipt than the HRS respondents. Second, there is a substantial difference in the probability of lump sum distribution receipt between low-income respondents in the HRS and the CPS. Those with labor income below $\$ 5000$ account for a much larger share of the lump sum distributions, and a much larger share of the dollar value of these payouts, in the HRS than in the CPS. The source of these disparities warrants further analysis.

The HRS also collects some information on how lump sum distributions were used, although respondents have fewer options than the CPS Employee Benefit Supplement provides. Table 5 summarizes the responses to these questions. The results confirm the substantial differences between recipientweighted and distribution-weighted statistics on the utilization of lump sums. While 33 percent of those who received lump sum distributions reported rolling them into IRAs or transferring them to the retirement plan of a new employer, 
their distributions accounted for 67 percent of all distributions reported in the HRS. $^{9}$

\section{Rollovers, Savings, and Lump Sum Distributions}

The decision to roll-over a lump sum distribution into an IRA, to transfer the assets to the retirement plan of a new employer, or to otherwise invest them is of central importance for analyzing the preservation of accumulated retirement assets. ${ }^{10}$ In this section, we analyze the factors that appear to influence such rollover or reinvestment decisions. We begin with a set of summary tables focusing on the age of the recipient and the size of the distribution, and then report estimates of linear probability models for the decision to channel lump sum distributions to IRAs or to other types of financial asset saving.

Throughout our analysis we consider two possible definitions of financial asset saving for a lump sum distribution. The first is rolling over the distribution

${ }^{9}$ The HRS does not indicate when a distribution was received; the CPS Employee Benefit Supplement does. This means that the HRS and CPS tabulations for amounts of distributions are not quite comparable: the CPS tabulations consider all distributions measured in 1993 dollars, while the HRS tabulations weight distributions by the reported nominal values.

${ }^{10}$ The decision of whether or not to "take" a lump sum distribution, by those who are eligible for such distributions, is also a critical determinant of the preservation of retirement saving assets. We discuss this further in the conclusion. 
to an IRA or a new employer's plan, and the second is rollover as well as investment in an IRA or other retirement plan, or investment in a saving account. ${ }^{11}$ A distribution that is saved through a saving account or other "traditional" saving plan will not accumulate as rapidly as a distribution that is transferred to a qualified retirement saving account, because taxes on asset income will slow asset growth. Neither of these definitions corresponds to the set of uses of lump sum distributions that do not diminish household net worth, as consumption spending would. That set would include paying down debts, purchasing durables, and a variety of other behaviors that were shown in several earlier tables.

To motivate our analysis, Table 6 presents probabilities of roll-over into an IRA or new employer pension plan, stratified by the size of the distribution and the age of the recipient at the time when the distribution was received. To be considered as a "rollover," the respondent had to indicate that this was at least one of the uses to which he or she put the distribution. We have done a similar analysis of the restricted sample of respondents who indicated that they devoted all of their distribution to a single use, with broadly similar findings. The table includes some empty cells corresponding to cases for which there

${ }^{11}$ The distinction between "rolled over into an IRA" and "invested in an IRA" is presumably the absence of a fiduciary-to-fiduciary transfer in the second case. 
were no individuals in the relevant age/income category in our sample of distribution recipients.

The results in Table 6 suggest a definite pattern: the probability of rollover is much lower in the upper left hand corner of the table than in the lower righthand corner. For those who receive distributions of more than $\$ 25,000$, the probability of rollover exceeds .50 , while for those who receive distributions of less than $\$ 1000$, the probability is less than .10 . There are similar substantial age differences in rollover rates, rising from less than twenty percent for those under the age of 35 to nearly 45 percent for those aged 55-64.

Table 7 presents similar estimates of the probability of that a distribution will be channeled to particular financial investments, by size and age of recipient. This probability is substantially greater (.38 on average) than the probability that it will be rolled over $(.22)$. The pattern across ages and size of distributions is nevertheless similar to that in Table 6 . Older recipients, and those who receive larger distributions, are more likely to use their distributions to invest in an IRA, roll over to an IRA or qualified plan, or invest in a saving account. These findings underscore our discussion in the last section of the important of distinguishing between the allocation of distributions and the allocation of distributed dollars. Large distributions are more likely to be rolled over or reinvested than smaller payouts. 
To provide further information on the behavior of recipients of lump sum distributions, Table 8 reports estimates of a linear probability model for rollover behavior. ${ }^{12}$ We report several different specifications. The first relates the probability of rollover to a set of categorical variables for age and size of distribution. The second specification augments the first with indicator variables for different levels of educational attainment, and the third adds current income to the specification as well. In each set of variables, the "lowest" category lage $<25$, distribution size $<\$ 1000$, less than a high school education, and income less than $\$ 10000$ ) is the excluded group.

The estimates confirm the patterns we observed in Tables 6 and 7, but the provide more information on the interaction between various effects. The indicator variables for age at time of receipt increase monotonically between ages 25 and 64, but there is a sharp decline in the probability of rollover for households over the age of 65 . There is also a clear increase in the probability of rollover as the size of the distribution rises. The probability that a distribution worth more than $\$ 25000$ will be rolled over is 25 percentage points higher than the analogous probability for a distribution worth less than $\$ 1000$,

\footnotetext{
${ }^{12}$ We have estimated models similar to those in Table 8 using standard discrete choice models (logit and probit), with results very similar to those from the linear probability models. We report the latter because of the easy interpretation of the coefficient estimates.
} 
and 18 percentage points higher than the probability for a distribution worth between $\$ 1000-5000$. The pattern of coefficients for the age and size of distribution categories is affected relatively little by controlling for household earned income. The most notable effect is an increase in the point estimate for the probability of saving rolling over a distribution if the recipient is between the ages of 55 and 64 .

The equations in the last two columns include education, and then education and income, indicator variables. Educational attainment does have an important predictive effect for the likelihood of rollover. The probability that those with a college degree will roll over a lump sum distribution is 15 percentage points higher than that for those with high school education. This differential is not just the result of differences in income: it is evident in equations with and without controls for earned income. There is some indication, although it is not statistically significant at standard confidence levels, that those with post-college education are less likely to roll over lump sum distributions than are those with only college degrees. The estimates in the last column of Table 8 add labor income to the set of control variables. The probability that a lump sum distribution is rolled over rises with the income of the recipient, with a particularly large effect for incomes over $\$ 50000$. 
Table 9 presents results analogous to those in Table 8, except the dependent variable is the probability that a lump sum distribution is rolled over, reinvested in an IRA, or invested in a saving account. The general patterns in Table 8 are confirmed in Table 9, with one exception. The coefficient on the indicator variable for age $65+$ in Table 8 is negative, implying that this age group is less likely to roll over a distribution than any other age group. This is not the case in Table 9. The coefficient estimates suggest that the age $65+$ group is more likely to channel a lump sum distribution to the various financial investments we consider than any other age group except the 55-64 group. The pattern of coefficients in education and income, and the effect of including these variables on the other estimated coefficients, is similar in Tables 8 and 9.

The low rate of rollover activity among those age $65+$ may reflect the impact of the excise tax on premature withdrawals on those in other age groups. For a person aged $59 \frac{1}{2}$ or above, an IRA functions like an ordinary investment vehicle with the additional benefit of tax deferral. It is therefore puzzling that households in this age group do not take advantage of this opportunity reduce their taxes.

As a check on the robustness of the CPS results, we also estimated similar equations for the allocation of lump sum distributions using the HRS. The results are shown in Table 10. Because the HRS age sample is limited, we 
do not include indicator variables for different age groups. We do include variables for the size of the distribution, the education of the respondent, and the respondent's current income. The results support the broad patterns of the CPS data, but the differential effects across subgroups are more muted than in the CPS. Increases in the size of the distribution raise the probability that it will be reinvested, as do increases in the respondent's education level up to a college degree. The same decline in the probability of reinvesting a distribution between those with college and post-college degrees is observed in the CPS and HRS data. There is also a small increase in the probability of reinvesting the distribution as the respondent's income rises, but the effect is only one fourth as large as that in the CPS.

Table 10 presents two equations estimated using the HRS data, exploiting the more detailed information on the history of lump sum distribution receipt. The first uses the distribution as the unit of observation, so a given household might appear more than once in the analysis if it received more than one payout. The second column limits the analysis to the largest distribution per household. There are no substantial differences between the two sets of results. 


\section{Conclusion and Future Directions}

This paper summarizes existing evidence on the receipt and utilization of lump-sum distributions from qualified retirement saving plans. Using information from the both Current Population Survey and the Health and Retirement Survey, we demonstrate that lump sum distributions are common, and that most such distributions are not rolled over into qualified retirement saving accounts. Most large distributions are rolled over, however, and the fraction of distribution dollars that are reinvested in saving vehicles is substantially greater than the fraction of distributions that are reinvested. We document a number of clear patterns with respect to the allocation of lump sum distributions. More educated workers, older workers, and higher income workers are more likely to roll these distributions into some type of retirement saving account.

Our analysis does not address whether individuals who are eligible for lump sum distributions take such distributions. There is at least some evidence that a substantial group of individuals who separate from their employer do not exercise their right to collect a lump sum, but rather become inactive participants in their employer's qualified pension plan. In 1991, for example, Form 5500 filings show that $6.0 \%$ of $401(k)$ participants, $14.5 \%$ of defined benefit plan participants, and $6.4 \%$ of defined contribution plan participants 
were "separated participants with vested rights to benefits." Because choosing not to receive a lump sum distribution is an important means of saving such potential distributions, this margin of individual behavior demands further analysis in the future.

This work represents the first step in a research program that complements our earlier work on eligibility for, and contribution behavior to, $401(\mathrm{k})$ plans, IRAs, and related saving vehicles. To evaluate the prospective impact of targeted retirement saving plans on the financial status of households that will reach retirement age early in the next century, it is essential to model three decisions: the decision to contribute to these accounts, the decision to roll-over funds from other accounts into these accounts, and the decision to withdraw funds from these accounts. A detailed age-specific profile with respect to each of these behaviors is needed as an input to any simulation algorithm for evaluating future financial status, and for comparison with data such as that in our (1994b) paper on actual financial status.

Our preliminary findings, when compared with information tabulated from tax return filings and reported in Yakoboski (1994), suggests the need for further data on the incidence and utilization of lump sum distributions. IRS tabulations suggest that a very substantial fraction of cash inflows to IRAs is now from rollovers rather than ordinary contributions. These data also suggest 
that the aggregate flow of premature withdrawals from IRAs and other qualified retirement plans is relatively small, no greater than $\$ 12$ billion in 1990 . This flow should be compared 1990 contributions to qualified retirement plans, IRAs, and Keogh accounts of nearly $\$ 115$ billion, and total assets in these accounts of $\$ 2.25$ trillion.

Our results have also stopped short of a behavioral model of household decisions with respect to lump sum distributions. In part this reflects the difficulty of modeling a decision that is in part embedded in a more complex choice problem, as many involuntary distributions as associated with job changes. We have not yet been able to focus on voluntary distributions from retirement saving plans, although that is one of our key interests in this area. We plan to address these questions in future work. 


\section{REFERENCES}

Andrews, E. S. 1991. Retirement savings and lump sum distributions. Benefits Quarterly 2: 47-58.

Atkins, G. L. 1986. Spend It or Save It? Pension Lump Sum Distributions and Tax Reform. Washington: Employee Benefit Research Institute.

Chang, A. 1993. Tax policy, lump sum pension distributions, and household saving. New York: Federal Reserve Bank of New York, mimeo.

Employee Benefit Research Institute. 1989. Pension Coverage and Benefit Entitlement: New Findings from 1988. EBRI Issue Brief 94 . Washington: Employee Benefit Research Institute.

Employee Benefit Research Institute. 1994. Employment-Based Retirement Income Benefits: Analysis of the April 1993 Current Population Survey. EBRI Issue Brief Number 153. Washington: Employee Benefit Research Institute.

Fernandez, P. A. 1992. Preretirement lump sum distributions. In J. Turner and D. Beller, eds., Trends in Pensions 1992. Washington: U.S. Department of Labor.

Gelbach, J. 1995. The disposition of lump sum payments from pension plans: A logit analysis. Cambridge, MA: Massachusetts Institute of Technology, Department of Economics, mimeo. 
Piacentini, J. S. 1990. Preservation of Pension Benefits. EBRI Issue Brief Number 98. Washington: Employee Benefit Research Institute.

Poterba, J. M., S. F. Venti, and D. A. Wise. 1994a. 401(k) plans and taxdeferred saving. In D. Wise, ed., Studies in the Economics of Aging. Chicago: University of Chicago Press. 105-138.

Poterba, J. M., S. F. Venti, and D. A. Wise. 1994b. Targeted retirement saving and the net worth of elderly Americans. American Economic Review Papers and Proceedings 84: 180-185.

Poterba, J. M., S. F. Venti, and D. A. Wise. 1995. Do 401(k) contributions crowd out other personal saving. Journal of Public Economics 58: 1-32. Yakoboski, P. 1994. Retirement program lump-sum distributions: Hundreds of billions in hidden pension income. EBR Issue Brief 146 (February 1994). 
Table 1: Total Lump-Sum Distributions from Pension Plans and Targeted Retirement Saving Accounts, 1990

Distributions from Accounts Other Than IRAs or SEPs
Distributions from IRAs or SEPs

\begin{tabular}{lll} 
& \multicolumn{2}{l}{ Number of Distributions } \\
Total & 8.20 million (100\%) & 2.60 million (100\%) \\
Normal & $1.72(21 \%)$ & $0.96(37 \%)$ \\
$\begin{array}{l}\text { Premature } \\
\text { Premature but exempt }\end{array}$ & $4.76(58 \%)$ & $1.24(53 \%)$ \\
from penalty tax & $0.25(3 \%)$ & $0.05(2 \%)$ \\
Death & $0.33(4 \%)$ & $0.18(7 \%)$ \\
Section 1035 Exchange & $0.58(7 \%)$ & 0.0 \\
Other or Uncoded & $0.58(7 \%)$ & $0.03(1 \%)$ \\
& & \\
& & \\
& Amount of Distributions & \\
Total & $\$ 107.2$ billion (100\%) & $\$ 18.6 \mathrm{billion}(100 \%)$ \\
& & $7.8(42 \%)$ \\
Normal & $35.4(33 \%)$ & $7.6(41 \%)$ \\
Premature & $34.3(32 \%)$ & $0.6(3 \%)$ \\
Premature but exempt & & $2.4(13 \%)$ \\
from penalty tax & $5.4(5 \%)$ & 0.0 \\
Death & $6.4(6 \%)$ & $0.2(1 \%)$ \\
Section 1035 Exchange & $7.5(7 \%)$ &
\end{tabular}

Source: Yakoboski (1994), based on tabulations of IRS Forms 1099-R for 1990, and authors' calculations. 
Table 2: Age-Specific Incidence of Lump-Sum Distribution Receipt, May 1993 CPS

\begin{tabular}{|c|c|c|c|}
\hline Age Group & Men & Women & All \\
\hline $16-20$ & $\begin{array}{l}0.2 \% \\
(1.1)\end{array}$ & $\begin{array}{l}0.0 \% \\
(1.1)\end{array}$ & $\begin{array}{l}0.1 \% \\
(0.8)\end{array}$ \\
\hline $21-30$ & $\begin{array}{l}4.9 \\
(0.5)\end{array}$ & $\begin{array}{l}5.7 \\
(0.5)\end{array}$ & $\begin{array}{l}5.2 \\
(0.4)\end{array}$ \\
\hline $31-40$ & $\begin{array}{l}11.8 \\
(0.5)\end{array}$ & $\begin{array}{l}13.0 \\
(0.5)\end{array}$ & $\begin{array}{l}12.4 \\
(0.3)\end{array}$ \\
\hline $41-50$ & $\begin{array}{l}12.7 \\
(0.5)\end{array}$ & $\begin{array}{l}14.0 \\
(0.6)\end{array}$ & $\begin{array}{l}13.3 \\
(0.4)\end{array}$ \\
\hline $51-55$ & $\begin{array}{l}12.7 \\
(0.9)\end{array}$ & $\begin{array}{l}9.7 \\
(1.0)\end{array}$ & $\begin{array}{l}11.3 \\
(0.7)\end{array}$ \\
\hline $56-60$ & $\begin{array}{c}11.7 \\
(1.1)\end{array}$ & $\begin{array}{l}10.0 \\
(1.2)\end{array}$ & $\begin{array}{l}11.0 \\
(0.8)\end{array}$ \\
\hline $61-64$ & $\begin{array}{l}12.3 \\
(1.5)\end{array}$ & $\begin{array}{l}9.8 \\
(1.7)\end{array}$ & $\begin{array}{l}11.2 \\
(1.1)\end{array}$ \\
\hline $65+$ & $\begin{array}{l}14.1 \\
(1.5)\end{array}$ & $\begin{array}{l}6.9 \\
(1.8)\end{array}$ & $\begin{array}{l}11.0 \\
(1.1)\end{array}$ \\
\hline TOTAL & $\begin{array}{l}9.9 \\
(0.3)\end{array}$ & $\begin{array}{l}10.0 \\
(0.3)\end{array}$ & $\begin{array}{l}9.9 \\
(0.2)\end{array}$ \\
\hline
\end{tabular}

Source: Authors tabulations from April 1988 and May 1993 Employee Benefit Supplements to the Current Population Survey. Each entry shows the probability that an individual in a given demographic category reported ever having received a lump sum distribution from a pension plan. Standard errors for the estimated probabilities are shown in parentheses. 
Table 3: CPS Respondents Reporting Any Part of Lump Sum Distribution Used for Various Purposes

\begin{tabular}{|c|c|c|c|c|}
\hline \multirow[b]{2}{*}{$\begin{array}{l}\text { Use of Lump Sum } \\
\text { Distribution }\end{array}$} & \multicolumn{2}{|c|}{ All Ages } & \multicolumn{2}{|c|}{ Ages 52-61 } \\
\hline & Jnweighted & $\begin{array}{l}\text { Value- } \\
\text { Weighted }\end{array}$ & Unweighted & $\begin{array}{c}\text { Value- } \\
\text { Weighted }\end{array}$ \\
\hline $\begin{array}{l}\text { Rolled Over into IRA or } \\
\text { New Employer Plan }\end{array}$ & $14.2 \%$ & $31.1 \%$ & $18.0 \%$ & $31.0 \%$ \\
\hline \multicolumn{5}{|l|}{ Invested in: } \\
\hline - IRA & 7.4 & 15.8 & 11.1 & 14.5 \\
\hline $\begin{array}{l}\text { - Insurance Annuity or } \\
\text { Other Retirement Program }\end{array}$ & n 2.0 & 4.6 & 2.7 & 5.8 \\
\hline - Savings Account & 9.6 & 7.0 & 12.1 & 8.4 \\
\hline - Other Financial Instrument & ht 5.9 & 11.6 & 9.9 & 17.5 \\
\hline - "Other Ways" & 2.2 & 1.7 & 2.1 & 1.2 \\
\hline $\begin{array}{l}\text { Used to Purchase or Start } \\
\text { A Business }\end{array}$ & 3.6 & 6.4 & 5.9 & 8.0 \\
\hline Bought House/Paid Mortgage & e 9.2 & 8.7 & 7.4 & 6.8 \\
\hline Paid Other Loans or Debt & 19.0 & 10.7 & 14.1 & 6.6 \\
\hline Bought Consumer Durables & 7.3 & 4.8 & 5.5 & 3.1 \\
\hline Paid Medical or Dental Bills & 1.9 & 1.5 & 1.5 & 1.7 \\
\hline Paid Educational Expenses & 3.0 & 2.5 & 1.5 & 1.6 \\
\hline Used for Everyday Expenses & s $\quad 21.7$ & 11.0 & 18.3 & 9.9 \\
\hline Other Spending & 6.5 & 4.8 & 6.2 & 7.2 \\
\hline Other Uses & 4.1 & 3.3 & 4.0 & 2.3 \\
\hline
\end{tabular}

Source: Authors' tabulations using May 1993 Employee Benefit Supplement to the Current Population Survey. 
Table 4: Lump Sum Distribution Receipt by Labor Income Category

Income Category

HRS

1993 CPS, All Ages 1993 CPS, Age 52-61

Probability of Ever Having Received a Lump Sum Distribution

$\begin{array}{llll}<5000 & 11.4 \% & 3.7 \% & 23.2 \% \\ 5000-10000 & 11.5 & 5.4 & 10.4 \\ 10000-20000 & 12.9 & 8.0 & 8.5 \\ 20000-30000 & 14.0 & 11.4 & 13.0 \\ 30000-50000 & 15.1 & 12.9 & 13.8 \\ 50000-75000 & 16.1 & 16.9 & 14.4 \\ 75000+ & 20.6 & 16.8 & 12.5 \\ \text { All Income Groups } & 13.9 & 10.0 & 12.1\end{array}$

Percentage of Lump Sum Distributions Reported in Each Income Group
$<5000$
$27.4 \%$
$0.1 \%$
$0.3 \%$

$5000-10000$

5.6

3.6

0.2

$10000-20000$

5.7

22.8

0.9

$20000-30000$

15.1

37.5

16.8

$30000-50000$

12.1

22.5

65.4

$50000-75000$

14.5

8.5

2.2

$75000+$

19.7

5.1

14.2

All Income Groups

100

100

100

Source: Authors' tabulations from 1992 Health and Retirement Survey and March 1993 Current Population Employee Benefit Supplement. The number of respondents in the HRS sample is 12654 , of whom 1624 reported receipt of a lump sum distribution. The CPS tabulations in the lower panel are not weighted by sampling probabilities, and they exclude individuals who do not report information on their last or current employer (firm size). This selection rule excludes some low-income households that are no longer working, and probably accounts for the difference between the HRS results and the CPS results for the HRS age sample. 
Table 5: HRS Evidence on Use of Lump Sum Distributions

\begin{tabular}{lcc}
$\begin{array}{l}\text { Use of Lump Sum } \\
\text { Distribution }\end{array}$ & $\begin{array}{l}\text { Percentage of } \\
\text { Those Receiving } \\
\text { Distributions }\end{array}$ & $\begin{array}{c}\text { Percentage of } \\
\text { Distributions }\end{array}$ \\
\hline $\begin{array}{l}\text { Rolled Into IRA or Transfer } \\
\text { to Other Retirement Assets }\end{array}$ & $33.2 \%$ & $66.8 \%$ \\
$\begin{array}{l}\text { Purchase of Annuity } \\
\text { Cash - Spent }\end{array}$ & 2.6 & 5.9 \\
Cash - Saved or Invested & 23.6 & 7.6 \\
Cash - Paid Bills & 12.1 & 7.6 \\
Cash - Other & 7.8 & 5.2 \\
Other & 15.3 & 6.7 \\
\hline
\end{tabular}

Source: Authors tabulations from 1992 Health and Retirement Survey. 
Table 6: Probability That Lump-Sum Distribution is Rolled Over to an IRA or to a New Employer's Plan; By Age of Receipt and Amount of Distribution

Distribution

Age When Received

Value $(\$ 1993)<25 \quad 25-34 \quad 35-44 \quad 45-54 \quad 55-64 \quad 65+$ All Ages

\begin{tabular}{|c|c|c|c|c|c|c|c|}
\hline$<500$ & $\begin{array}{c}.024 \\
(.040)\end{array}$ & $\begin{array}{l}.048 \\
(.037)\end{array}$ & $\begin{array}{l}.089 \\
(.055)\end{array}$ & $\begin{array}{l}.000 \\
(.112)\end{array}$ & $\begin{array}{l}.000 \\
(.606)\end{array}$ & & $\begin{array}{l}.046 \\
(.024)\end{array}$ \\
\hline $501-1000$ & $\begin{array}{l}.093 \\
(.058)\end{array}$ & $\begin{array}{l}.073 \\
(.034)\end{array}$ & $\begin{array}{l}.086 \\
(.069)\end{array}$ & $\begin{array}{l}.000 \\
(.111)\end{array}$ & $\begin{array}{l}.000 \\
(.473)\end{array}$ & $\begin{array}{l}.000 \\
(.301)\end{array}$ & $\begin{array}{l}.078 \\
(.027)\end{array}$ \\
\hline $1001-2500$ & $\begin{array}{l}.035 \\
(.044)\end{array}$ & $\begin{array}{l}.135 \\
(.025)\end{array}$ & $\begin{array}{c}.164 \\
(.034)\end{array}$ & $\begin{array}{l}.129 \\
(.060)\end{array}$ & $\begin{array}{l}.689 \\
(.202)\end{array}$ & $\begin{array}{l}.000 \\
(.270)\end{array}$ & $\begin{array}{l}.129 \\
(.018)\end{array}$ \\
\hline $2501-5000$ & $\begin{array}{l}.009 \\
(.057)\end{array}$ & $\begin{array}{l}.160 \\
(.025)\end{array}$ & $\begin{array}{l}.211 \\
(.045)\end{array}$ & $\begin{array}{l}.189 \\
(.063)\end{array}$ & $\begin{array}{l}.350 \\
(.113)\end{array}$ & & $\begin{array}{l}.158 \\
(.019)\end{array}$ \\
\hline 5001-10000 & $\begin{array}{l}.007 \\
(.072)\end{array}$ & $\begin{array}{l}.250 \\
(.029)\end{array}$ & $\begin{array}{l}.300 \\
(.034)\end{array}$ & $\begin{array}{c}.431 \\
(.066)\end{array}$ & $\begin{array}{l}.201 \\
(.093)\end{array}$ & $\begin{array}{l}.000 \\
(.193)\end{array}$ & $\begin{array}{l}.259 \\
(.020)\end{array}$ \\
\hline $10001-15000$ & $\begin{array}{l}.156 \\
(.188)\end{array}$ & $\begin{array}{l}.117 \\
(.039)\end{array}$ & $\begin{array}{c}.349 \\
(.046)\end{array}$ & $\begin{array}{l}.415 \\
(.069)\end{array}$ & $\begin{array}{l}.759 \\
(.137)\end{array}$ & $\begin{array}{l}.000 \\
(.477)\end{array}$ & $\begin{array}{l}.265 \\
(.027)\end{array}$ \\
\hline $15001-25000$ & $\begin{array}{l}.417 \\
(.285)\end{array}$ & $\begin{array}{l}.248 \\
(.042)\end{array}$ & $\begin{array}{c}.337 \\
(.049)\end{array}$ & $\begin{array}{l}.410 \\
(.063)\end{array}$ & $\begin{array}{l}.376 \\
(.099)\end{array}$ & & $\begin{array}{l}.319 \\
(.028)\end{array}$ \\
\hline $25000-50000$ & $\begin{array}{l}.000 \\
(.280)\end{array}$ & $\begin{array}{l}.386 \\
(.077)\end{array}$ & $\begin{array}{c}.459 \\
(.053)\end{array}$ & $\begin{array}{l}.693 \\
(.060)\end{array}$ & $\begin{array}{l}.317 \\
(.090)\end{array}$ & $\begin{array}{l}.000 \\
(.252)\end{array}$ & $\begin{array}{l}.483 \\
(.033)\end{array}$ \\
\hline $50000+$ & $\begin{array}{l}.000 \\
(.463)\end{array}$ & $\begin{array}{l}.586 \\
(.115)\end{array}$ & $\begin{array}{c}.792 \\
(.058)\end{array}$ & $\begin{array}{l}.664 \\
(.065)\end{array}$ & $\begin{array}{c}.592 \\
(.077)\end{array}$ & & $\begin{array}{l}.686 \\
(.036)\end{array}$ \\
\hline TOTAL & $\begin{array}{l}.044 \\
(.022)\end{array}$ & $\begin{array}{l}.161 \\
(.012)\end{array}$ & $\begin{array}{l}.279 \\
(.015)\end{array}$ & $\begin{array}{l}.387 \\
(.022)\end{array}$ & $\begin{array}{l}.420 \\
(.038)\end{array}$ & $\begin{array}{l}.000 \\
(.097)\end{array}$ & $\begin{array}{l}.215 \\
(.008)\end{array}$ \\
\hline
\end{tabular}

Source: Authors' tabulations from 1993 Current Population Survey, Employee Benefit Supplement. Affirmative answers to questions on whether the lump sum distribution was rolled over into an IRA or into a new employers play, or invested in an IRA, were used to define the positive value for the indicator variable. 
Table 7: Probability That Lump-Sum Distribution is Reinvested, By Age of Receipt and Amount of Distribution

\begin{tabular}{|c|c|c|c|c|c|c|c|}
\hline \multicolumn{3}{|c|}{ Value $(\$ 1993)$ of } & \multicolumn{4}{|c|}{ Age When Received } & \multirow[b]{2}{*}{ TOTAL } \\
\hline $\begin{array}{l}\text { Value (\$1993) } \\
\text { Distribution }\end{array}$ & of $<25$ & $25-34$ & $35-44$ & $45-54$ & $55-64$ & $65+$ & \\
\hline$<500$ & $\begin{array}{l}.114 \\
(.047)\end{array}$ & $\begin{array}{l}.149 \\
(.044)\end{array}$ & $\begin{array}{l}.166 \\
(.065)\end{array}$ & $\begin{array}{l}.148 \\
(.080)\end{array}$ & $\begin{array}{l}.000 \\
(.717)\end{array}$ & & $\begin{array}{l}.139 \\
(.028)\end{array}$ \\
\hline $501-1000$ & $\begin{array}{l}.172 \\
(.068)\end{array}$ & $\begin{array}{l}.182 \\
(.041)\end{array}$ & $\begin{array}{l}.200 \\
(.082)\end{array}$ & $\begin{array}{l}.082 \\
(.131)\end{array}$ & $\begin{array}{l}.000 \\
(.560)\end{array}$ & $\begin{array}{l}1.000 \\
(.356)\end{array}$ & $\begin{array}{l}.194 \\
(.031)\end{array}$ \\
\hline $1001-2500$ & $\begin{array}{l}.210 \\
(.052)\end{array}$ & $\begin{array}{l}.293 \\
(.030)\end{array}$ & $\begin{array}{l}.389 \\
(.040)\end{array}$ & $\begin{array}{l}.236 \\
(.072)\end{array}$ & $\begin{array}{l}1.000 \\
(.239)\end{array}$ & $\begin{array}{l}.000 \\
(.320)\end{array}$ & $\begin{array}{l}.305 \\
(.021)\end{array}$ \\
\hline $2501-5000$ & $\begin{array}{l}.174 \\
(.068)\end{array}$ & $\begin{array}{l}.313 \\
(.030)\end{array}$ & $\begin{array}{l}.422 \\
(.053)\end{array}$ & $\begin{array}{l}.414 \\
(.074)\end{array}$ & $\begin{array}{l}.496 \\
(.133)\end{array}$ & & $\begin{array}{l}.329 \\
(.023)\end{array}$ \\
\hline $5001-10000$ & $\begin{array}{l}.235 \\
(.085)\end{array}$ & $\begin{array}{l}.390 \\
(.034)\end{array}$ & $\begin{array}{l}.486 \\
(.041)\end{array}$ & $\begin{array}{l}.506 \\
(.078)\end{array}$ & $\begin{array}{l}.485 \\
(.110)\end{array}$ & $\begin{array}{l}.087 \\
(.229)\end{array}$ & $\begin{array}{l}.420 \\
(.023)\end{array}$ \\
\hline $10001-15000$ & $\begin{array}{l}.413 \\
(.223)\end{array}$ & $\begin{array}{l}.378 \\
(.047)\end{array}$ & $\begin{array}{l}.558 \\
(.054)\end{array}$ & $\begin{array}{l}.626 \\
(.081)\end{array}$ & $\begin{array}{l}1.000 \\
(.162)\end{array}$ & $\begin{array}{l}1.000 \\
(.565)\end{array}$ & $\begin{array}{l}.502 \\
(.032)\end{array}$ \\
\hline $15001-25000$ & $\begin{array}{l}.417 \\
(.338)\end{array}$ & $\begin{array}{l}.541 \\
(.050)\end{array}$ & $\begin{array}{l}.676 \\
(.058)\end{array}$ & $\begin{array}{l}.651 \\
(.075)\end{array}$ & $\begin{array}{l}.810 \\
(.118)\end{array}$ & & $\begin{array}{l}.627 \\
(.033)\end{array}$ \\
\hline $25000-50000$ & $\begin{array}{l}.000 \\
(.331)\end{array}$ & $\begin{array}{l}.675 \\
(.091)\end{array}$ & $\begin{array}{l}.584 \\
(.062)\end{array}$ & $\begin{array}{l}.822 \\
(.071)\end{array}$ & $\begin{array}{l}.724 \\
(.107)\end{array}$ & $\begin{array}{l}.000 \\
(.300)\end{array}$ & $\begin{array}{l}.671 \\
(.039)\end{array}$ \\
\hline $50000+$ & $\begin{array}{l}.000 \\
(.549)\end{array}$ & $\begin{array}{l}.789 \\
(.137)\end{array}$ & $\begin{array}{l}.908 \\
(.069)\end{array}$ & $\begin{array}{l}.930 \\
(.078)\end{array}$ & $\begin{array}{l}.865 \\
(.091)\end{array}$ & & $\begin{array}{l}.888 \\
(.043)\end{array}$ \\
\hline TOTAL & $\begin{array}{l}.186 \\
(.026)\end{array}$ & $\begin{array}{l}.322 \\
(.014)\end{array}$ & $\begin{array}{l}.480 \\
(.018)\end{array}$ & $\begin{array}{l}.569 \\
(.026)\end{array}$ & $\begin{array}{l}.728 \\
(.045)\end{array}$ & $\begin{array}{l}.385 \\
(.115)\end{array}$ & $\begin{array}{l}.393 \\
(.009)\end{array}$ \\
\hline
\end{tabular}

Source: Authors' tabulations from 1993 Current Population Survey, Employee Benefit Supplement. Distributions were defined as saved if the respondent indicated that they were rolled over into an existing IRA or new employer's retirement plan, invested in an IRA or other retirement plan, or invested in a saving account. 
Table 8: Linear Probability Models for Decision to Roll Over Lump Sum Distribution

Constant

$-0.008$

(0.026)

Age When Received Distribution:

$25-34$

0.067

(0.027)

0.158

(0.030)

0.196

(0.035)

$45-54$

0.245

(0.049)

$-0.122$

(0.150)

$65+$

0.073

(0.023)

0.165

(0.028)

0.252

(0.026)

Size of Distribution:

1000-5000

5000-10000

$>10000$
$-0.078$

(0.047)

0.055

(0.027)

0.155

(0.029)

0.209

(0.035)

0.268

(0.049)

$-0.108$

(0.148)
$-0.103$

(0.057)

0.065

0.054

0.054
$(0.028)$

(0.023)

0.155

(0.031)

0.214

(0.038)

0.356

(0.055)

0.149

(0.028)

$-0.058$

(0.149)

0.236

(0.026)

0.064

(0.024)

0.150

(0.030)

0.214

(0.028)

Education Indicators:

High School
0.014
(0.043)
$-0.010$
0.069
(0.047)
(0.043)
0.052
(0.047)
0.175
0.143
(0.043)
(0.048)
0.106
(0.045)
0.045
(0.051)

Some College

College Degree

College +

Income Indicators:

10 - $20 K$

0.037

(0.033)

$20-30 K$

0.044

(0.034)

$30-50 K$

0.076

(0.034)

$>50 K$

0.137

(0.040)

Adjusted $\mathrm{R}^{2}$

0.101

0.122

.134

Source: Authors' tabulations using data from the May 1993 Employee Benefit Supplement to the Current Population Survey. Standard errors are show in parentheses. 
Table 9: Linear Probability Models for Decision to Reinvest Lump Sum Distribution

\begin{tabular}{lccc}
\hline Constant & 0.087 & -0.068 & -0.069 \\
& $(0.030)$ & $10.054)$ & $10.067)$ \\
Age When Received Distribution: & & \\
$25-34$ & 0.081 & 0.071 & 0.069 \\
& $(0.031)$ & $(0.031)$ & $10.033)$ \\
$35-44$ & 0.178 & 0.177 & 0.181 \\
& $(0.034)$ & $(0.034)$ & $10.036)$ \\
$45-54$ & 0.214 & 0.230 & 0.232 \\
& $(0.041)$ & $10.041)$ & $10.045)$ \\
$55-64$ & 0.353 & 0.379 & 0.442 \\
& $(0.057)$ & $(0.057)$ & $10.065)$ \\
$65+$ & 0.311 & 0.321 & 0.443 \\
& $(0.173)$ & $(0.172)$ & $10.185)$
\end{tabular}

Size of Distribution:

$1000-5000$

$\begin{array}{ccc}0.115 & 0.109 & 0.120 \\ (0.027) & (0.026) & (0.028)\end{array}$

$5000-10000$

0.185

0.169

0.185

(0.032)

(0.032)

(0.035)

$>10000$

0.363

0.352

0.342

(0.030)

(0.030)

(0.033)

Education Indicators:

High School
0.114
0.105
(0.050)
(0.054)
0.158
0.155
(0.049)
(0.055)
0.254
0.228
(0.050)
(0.057)
0.166
(0.053)
0.105
(0.060)

Some College

College Degree

College +

Income Indicators:

10 - 20K

$-0.012$

(0.040)

$20-30 K$

$-0.006$

(0.040)

$30-50 K$

0.039

(0.040)

$>50 \mathrm{~K}$

0.101

(0.047)

Adjusted $\mathrm{R}^{2}$

0.129

0.143 .151

Source: Authors' tabulations using data from the May 1993 Employee Benefit Supplement to the Current Population Survey. Standard errors are show in parentheses. 
Table 10: Linear Probability Models for Decision to Reinvest Lump Sum Distribution

Allowing Multiple

Distributions per Household
Largest Distribution Per Household

Constant

$-0.012$

$-0.015$

(0.011)

(0.013)

Size of Distribution:

$1000-5000$

0.239

0.242

(0.015)

(0.018)

5000-10000

0.298

0.290

(0.020)

(0.024)

$>10000$

0.317

0.313

(0.012)

(0.014)

Education Indicators:

High School

$$
0.033
$$

0.031

(0.013)

(0.015)

Some College

0.043

0.045

(0.015)

(0.018)

College Degree
0.084
0.097
(0.017)
(0.021)

College +

0.017

0.028

(0.018)

(0.022)

Income Indicators:

$30-50 K$

$-0.005$

$-0.002$

(0.012)

(0.015)

$>50 K$

0.022

0.023

(0.013)

(0.015)

Adjusted $\mathrm{R}^{2}$

0.183

0.174

Source: Authors' tabulations using data from the 1992 Health and Retirement Survey. Standard errors are shown in parentheses. 